\title{
PENGARUH PENGEMBANGAN PERKEBUNAN RAKYAT TERHADAP KEBERDAYAAN DAN INVESTASI MASYARAKAT DESA HUTAN
}

\author{
The Effect of Community Plantation Development to the Empowerment and the Investment \\ Forest Village Community
}

\author{
Dheva Sari Silaban*) dan Saharuddin
}

Departemen Sains Komunikasi dan Pengembangan Masyarakat, Fakultas Ekologi Manusia, Institut Pertanian Bogor

*) E-mail: dhevasari83@gmail.com

\begin{abstract}
Community Plantation (not incorporated) are plantations held or managed by planters for small businesses grouped in smallholder tree crops and plantation household business people. In its management, smallholder plantations can affect the level of empowerment and investment communities working on forest villages. The purpose of this study is to analyze the role of government in encouraging or influencing the empowerment of farmers to invest in plantations. The approach used to analyze the effect is the quantitative approach with survey method that is supported by the relevant qualitative data. The results showed the level of government's role does not affect the level of empowerment of forest villagers. However, the level of the role of government affect the rate of integration of commodity farm forest villagers. At the level of investment, the implementation of people's plantation management does not affect the level of community investment significantly.
\end{abstract}

Keywords: role of governments, forest villagers, integration

\section{PENDAHULUAN}

Beberapa pertimbangan pengalokasian lahan di hutan adalah keberdayaan masyarakat dan investasi yang harusmenguntungkan. Konsesihutan begitusering diberikan kepadaperusahaan-perusahaan kehutanan karena alasan keberdayaan dan investasi tersebut. Dalam bentuk lain, pengalokasian yang juga menguntungkan dari pihak masyarakat adalah perkebunan rakyat. Berdasarkan Buku Pembakuan Statistik Perkebunan 2007, mengacu pada UU No 18 Tahun 2004 mengenai Perkebunan serta Buku Konsep dan Definisi Baku Statistik Pertanian (BPS), perkebunan rakyat (tidak berbadan hukum) adalah perkebunan yang diselenggarakan atau dikelola oleh rakyatpekebun yang dikelompokkan dalam usaha kecil tanaman perkebunan rakyat dan usaha rumah tangga perkebunan rakyat.

Hutan yang dimanfaatkan masyarakat untuk kegiatan pertanian memiliki banyak sistem seperti pemanfaatan lahan di bawah tegakan (PLDT) yang menurut Mustofa (2011) merupakan alternatif dalam akses pemanfaatan lahan hutan yang diberikan kepada masyarakat sekitar hutan. Menurut Irawanti et al. (2012), jenis HBK dari lahan hutan rakyat yang kontribusinya besar terhadap pendapatan petani di tiga desa lokasi studi adalahjenis tanaman buah-buahan (31,58-75,11\%) dan tanaman perkebunan (22,13-55,41\%). Pemanenan bergilir dapat dilakukan sepanjang produksi positif. Sedangkan di Desa Sangkima lahan perkebunan dengan beragam komoditas yang diusahakan menjadi investasi yang menguntungkan disamping pekerjaan utamanya. Investasi dalam bentuk tabungan untuk menambah modal atau pengembangan modal dilaksanakan untuk pengembangan kualitas sumberdaya manusia terutama bidang pendidikan anggota keluarga dan kesehatannya. Penelitian ini akan mengidentifikasi faktor keberdayaan dan investasi hasil hutan kemasyarakatan oleh masyarakat desa. Kemudian akan melihat juga pengaaruh perkebunan rakyat sebagai suatu sistem pengelolaan hutan mampu mempertahankan kelestarian hutan dan menyokong ekonomi petani.

Salah satu perkebunan rakyat juga terjadi di Desa Sangkima, Kecamatan Sangatta Selatan, Kabupaten Kutai Timur, Kalimantan Timur. Desa ini merupakan salah satu desa poros jalan Sangatta-Bontang yang membelah Taman Nasional Kutai (TNK) (Sambodo 2004). Para petani di lokasi menerapkan sistem pertanian berdasarkan berbagai pengaruh. Masyarakat Desa Sangkima diduga telah mengalami keberdayaan dan mampu berinvestasi dalam perkebunan. Pemerintah daerah sebagai regulator kelangsungan hidup ketetapan wilayahnya termasuk bertanggungjawab terhadap kemajuan daerahnya. Oleh sebab itu dapat dianalisa bagaimana peran pemerintah daerah dalam mendorong investasi petani di perkebunan?

Selain pemerintah sebagai pengatur keberlangsungan hidup masyarakat pada daerahnya, masyarakat sendiri berhak meningkatkan taraf hidup dan bebas mengaplikasikan sumberdayanya dalam daerah namun dalam batas tertentu eksploitasi yang diizinkan. Oleh sebab itu perlu dianalisa bagaimana pola investasi petani diperkebunan rakyat? Dengan invetasi tersebut pula bagaimana tingkat keberdayaan petani sebagai pengelola perkebunan?

Dari peran yang dijalankan pemerintah, perlu diketahui bagamana pengaruh peran pemerintah terhadap keberdayaan petani. Kemudian bagaimana pengaruh keberdayaan 
terhadap investasi petani?

Penelitian ini bertujuan menjawab masalah penelitian yakni menganalisis peran pemerintah daerah dalam mendorong investasi petani di perkebunan, menganalisis pola investasi petani di perkebunan rakyat, menganalisis tingkat keberdayaan petani, menganalisis pengaruh peran pemerintah daerah terhadap keberdayaan petani, dan menganalisis pengaruh keberdayaan terhadap investasi.

Adapun kegunaan penelitian ini bagi akademisi menjadi referensi penelitian berikutnya atau akan mengembangakan ide dari landasan penelitian ini. Selain itu, dapat juga berguna untuk membangun gagasan akademisi dalam merealisasikan pembangunan perkebunan rakyat. Selain bagi akademisi, penelitian ini juga dapat berguna bagi pemerntah yakni dapat menjadi bahan evaluasi dan mengetahui pandangan masyarakat terhadap perannya dalam melaksanakan perannya. Akhirnya, pada masyarakat sendiri penelitian ini dapat dipakai dalam membangun kesadaran dan sebagai kekuatan ilmiah dalam membangun kehidupan lebih baik terutama untuk mengintervensi pemerintah dalam pembangunan partisipatif.

\section{TINJAUAN PUSTAKA}

Dinamika penerimaan perkebunan dalam bentuk agroforestri di masyarakat menurut Budiadi et al. (2012), bagian utama dari pengelolaan hutan adalah kegiatan silvikultur yaitu tindakan melakukan manipulasi tegakan hutan dengan mengatur struktur dan komposisi pohon dan vegetasi lainnya. Kegiatan silvikultur ini dirumuskan untuk mencapai tujuan pemanfaatan dalam rambu-rambu kebijakan pengusahaan yang ditetapkan oleh sang pemilik hutan itu, siapapun dia.

Konteks ideologi dan politik kehutanan masa lalu, khususnya di jaman penjajahan, sumberdaya hutan semata-mata dipersepsikan sebagai sumber keuntungan dan bukan sebagai sumber kehidupan bagi masyarakat. Paradigma baru kehutanan menolak praktik pengelolaan hutan yang tidak pro rakyat dan menerima pendekatan forest ecosystem management yang memposisikan sumberdaya hutan sekaligus sebagai ruang kehidupan.

Sistem yang digunakan dalam kegiatan agroforestri disebut tumpangsari dan dipraktikkan pada awal proses pembangunan tanaman hutan. Tumpangsari yang diadopsi dari praktik taungya di Myanmar memiliki 4 tujuan, yaitu 1) menghemat biaya tanaman, 2) memperoleh tambahan penghasilan dari usaha pertanian, 3) pemeliharaan tanaman yang lebih baik, dan 4) membantu memenuhi kekurangan lahan pertanian setempat. Dari karakteristik keberhasilan agroforestri, yaitu produktivitas, kelestarian hasil dan adoptabilitas, hanya bagian produktivitasnya sajalah yang dapat dipenuhi, sedang yang dua terakhir tidak pernah bisa tercapai karena ada konflik kepentingan antara rimbawan dan petani dan memang posisi tawar keduanya tidak berada pada level yang sejajar.

\section{Dinamika manajemen komponen agroforestry}

Komponen sistem agroforestri yang diurus yaitu pohon (tanaman berkayu), tanaman pertanian, dan hewan (ternak termasuk ikan). Pengaturan ketiga komponen itu dilakukan mengikuti ruang dan waktu yang ditetapkan secara arbitrary sesuai dengan keperluan pengelolanya. Di lapangan kehutanan, pengaturan dimulai dengan penentuan jarak tanam tanaman pokok hutan, kemudian bagian lahan yang dikorbankan untuk tanaman pertanian ditetapkan.

Penguasaan karakter ekofisiologi tanaman kondisi kompetitif dapat diubah menjadi interaksi fasilitatif (Budiadi et al. 2012). Salah satu faktor keberhasilan agroforestry adalah ketepatan pemilihan jenis, maka dalam perkembangan ini ketepatan kombinasi jenis merupakan langkah yang penting untuk menjamin keberhasilan sistem tersebut. Kombinasi yang sudah mementingkan aspek pengaturan vertikal yang baik dicirikan oleh pengelolaan tumbuhan bawah yang tepat karena toleran terhadap naungan pohon pohonan dan produknya bernilai tinggi.

\section{Pengelolaan Hutan dalam Bentuk Perkebunan Rakyat}

Berdasarkan Buku Pembakuan Statistik Perkebunan 2007, mengacu pada UU No 18 Tahun 2004 mengenai Perkebunan serta Buku Konsep dan Definisi Baku Statistik Pertanian(BPS), Perkebunan rakyat (tidak berbadan hukum) adalah perkebunan yang diselenggarakan atau dikelola oleh rakyat/pekebun yang dikelompokkan dalam usaha kecil tanaman perkebunan rakyat dan usaha rumah tangga perkebunan rakyat. Perkebunan rakyat menempatkan masyarakat sebagai pelaku utama. Hutan yang diubah menjadi kebun pun dilakukan dengan usaha sendiri atau kelompok berupa Kelompok Tani. Sistem pengelolaan hutan meliputi seluruh kegiatan pengelolaan secara komprehensif meliputi menanam, memelihara, dan memanfaatkan. Untuk pelaksanaan pengelolaan perlu penguatan kelembagaan kemitraan antara masyarakat, dunia usaha, dan pemerintah. Awang dalam Widodo (2006) menyebutkan butir-butir penting dari hutan kemasyarakatan:

(1) fokus pengelolaan hutan pada upaya perlindungan, konservasi, dan kegiatan ekonomi;

(2) aktor utama pengelola hutan adalah masyarakat;

(3) pemerintah sebagai fasilitator, regulator, dan pengawas;

(4) Pemberdayaan dan penguatan masyarakat lokal dan industri kehutanan; dan

(5) pelaksanaan sesuai dengan kebudayaan

Pengelolaan hutan kemasyarakatan adalah salah satu prinsip pengelolaan hutan yang seharusnya memperhatikan kebutuhan dan kesejahteraan masyarakat yang hidupnya tergantung pada hutan atau berbasis pada hutan. Ada berbagai macam tafsiran mengenai pengertian berbasis masyarakat. Sebagian pihak mengatakan hak, kedaulatan dan keterlibatan masyarakat dalam mengambil keputusan menyangkut masyarakat. Sistem dalam pengelolaan perkebunan rakyat tidak lepas dari peran pemerintah yang dapat membentuk keabsahannya. Peran tersebut dapat ditinjau dari:

1. Fokus pemerintah. Kefokusan pemerintah dapat diperhatikan dari tujuan dan orientasinya dalam mengelola hutan. Fokus tersebut dapat berupa fokus untuk konservasi, kegiatan ekonomi, maupun kolaborasi dari konservasi dan kegiatan ekonomi. 
2. Fasilitasi. Peran fasilitator pemerintah dapat dilihat dari kemampuan menyediakan input perkebunan rakyat dan perlengkapannya.

3. Regulasi. Peran regulator dari pemerintah juga penting sehingga dipandang sangat krusial untuk diidentifikasi. Regulasi pemerintah dapat pula ditinjau dari tingkatan norma. Tingkatan internalisasi norma-norma dapat dinilai dengan menggunakan tingkatan norma yang melembaga berdasarkan kuat atau lemahnya ikatan yang dimiliki oleh norma tersebut.

4. Pengawasan. Kontrol sosial bertujuan untukmencapai keserasian antara stabilitas dengan perubahanperubahan dalam masyarakat (Kolopaking et al. 2003). Suatu sistem kontrol sosial bertujuan untuk mencapai keadaan damai melalui keserasian antara kepastian dengan keadilan/kesebandingan.

\section{Keberdayaan Masyarakat dalam Kemitraan pada Pengelolaan Hutan Kemasyarakatan}

Tujuan keberdayaan merupakan ukuran kemandirian terutama bagi petani. Pemberdayaan (empowerment) bermakna pemberian kekuasaan sebagai sebuah proses yang mempunyai tiga tahapan: penyadaran, pengkapasitasan, dan pendayaan (Wrihatnolo dan Dwidjowijoto 2007). Dalam tahap penyadaran, target yang hendak diberdayakan diberi "pencerahan" berupa pemberian penyadaran bahwa mereka mempunyai hak untuk mempunyai "sesuatu". Ciri-ciri masyarakat yang telah berdaya menurut Sumardjo et al. (2004) adalah sebagai berikut : a) mampu memahami diri dan potensinya, b) mampu merencanakan (mengantisipasi kondisi perubahan kedepan) dan mengarahkan dirinya sendiri, c) memiliki kekuatan untuk berunding dan bekerjasama secara saling menguntungkan dengan "bargaining power" yang memadai, d) bertanggung jawab atas tindakan sendiri (Parson, et.al. dalam Widodo 2006).

\section{Tindakan Konservasi Tanah dan Air untuk Mengatasi Banjir dan Kekeringan}

Menurut Arsyad (2006) banjir yang menggenangi lahanlahan kota dan pedesaan atau pertanian pada musim hujan terjadi sebagai akibat tidak tertampungnya aliran permukaan, yaitu air yang mengalir, dipermukaan tanah, oleh sungai dan saluran air lainnya. Aliran permukaan adalah bagian dari air hujan yang tidak dapat meresap ke dalam tanah, disebabkan kemampuan tanah menyerap air yang berkurang sebagai akibat dari kegiatan manusia yang mengurangi kapasitas infiltrasi tanah dan kesempatan air untuk meresap ke dalam tanah. Infiltrasi adalah peristiwa masuknya air ke dalam tanah, yang umumnya (tetapi tidak mesti) melalui permukaan dan secara vertika. Sebagai akibat ikutan tidak adanya atau berkurangnya air yang meresap dan masuk ke dalam tanah, maka tidak ada air yang tersimpan di dalam tanah (ground water) yang akan masuk ke dalam sungai, ke dalam sumur, dan ke dalam badan air lainnya pada musim kemarau, yang mengakibatkan kekeringan sungai, sumur, dan lahan-lahan pertanian. Fluktuasi debit sungai dalam keadaan demikian ini sangat besar; pada musim hujan debit sungai tidak tertampung oleh sungai, sedangkan pada musim kemarau hampir tidak ada air yang mengalir di dalam sungai. Jadi banjir di musim hujan dan kekeringan di musim kemarau adalah dua sisi mata uang yang saling berkaitan.

\section{Moda Produksi Multi Suku dalam Pengelolaan Sumber- Sumber Agraria}

Menurut Soetarto (2007) persoalan pembentukan entitas sosial multi suku, khususnya pada desa-desa 'baru' yang dibentuk dalam rangka program transmigrasi antar pulau maupun transmigrasi lokal (translok), seringkali menimbulkan potensi friksi bahkan konflik sosial. Dalam konteks desa-desa transmigrasi di Indonesia persoalan tersebut mengikutsertakan pula perihal perbedaan moda produksi (mode of production) yang dibawakan oleh masing-masig suku yang menjadi warga baru. Pada gilirannya perbedaan moda produksi berimplikasi terhadap berhasil tidaknya proses pembentukan entitas sosial baru (komunitas desa) itu sendiri secara sosiologis.

Dengan kata lain kebijakan pemerintah yang langsung atau tidak langsung turut mempertahankan terpeliharanya sekat-sekat perbedaan moda produksi dalam pengelolaan sumber-sumber agraria lokal oleh masing-masing suku maka ia berpotensi menguatkan eksklusivisme suku-suku yang bersangkutan. Sebaliknya kebijakan yang memberi peluang untuk proses saling belajar dan membuka diri antar warga suku yang berbeda dalam pengelolaan sumber-sumber agraria dapat menciptakan ruang bagi pembentukan moda produksi baru (formasi sosial) yang akomodatif. Hal terakhir ini penting bagi penciptaan 'stabilitas lingkungan' (Soetarto 2007).

Berdasarkan penelitian Soetarto (2007) moda produksi masing-masing kelompok suku mewujud dalam pilihan tanaman pokok yang berbeda. Kelompok suku asli dengan jagung, kopi yang sebagian berorientasi pada kebutuhan rumah tangga dan sebagian lagi untuk pasar lokal dengan nilai jualnya relatif rendah. Sementara kelompok suku pendatang khususnya Suku Bugis dengan tanaman kakao yang berorientasi pada kebutuhan ekspor sehingga nilai jualnya relatif tinggi. Perbedaan moda produksi yang berbeda ini pada gilirannya menyebabkan kelompok suku pendatang lebih mendominasi aktivitas ekonomi lokal (tampil sebagai formasi sosial), misalnya dengan membuka warung, mengisi pasokan pasar dengan bahan-bahan kebutuhan sehari-hari, dan sebagainya. Ini semua berakibat muncul kesenjangan sosial yang cukup menyolok antara kelompok suku asli dan pendatang.

\section{Investasi Masyarakat di Sektor Perkebunan}

Setyopurwanto dan Pudjihardjo (2013) menyatakan bahwa pertumbuhan ekonomi merupakan perbandingan kenaikan pendapatan (GDP) antar tahun bersangkutan terhadap tahun sebelumnya. Tingkat kemajuan suatu pembangunan dapat dilihat melalui pencapaian tingkat pertumbuhan pendapatan perkapita (income per capita).

Menurut Setyopurwanto dan Pudjihardjo (2013) pendidikan merupakan bentuk investasi sumber daya manusia yang sama pentingnya dengan investasi dalam modal fisik untuk mencapai kesuksesan ekonomi jangka panjang suatu negara. Kualitas sumber daya manusia sangat diperukan dalam 
peningkatan kualitas faktor produksi. Kualitas faktor produksi sumber daya manusia sangat dipengaruhi oleh tingkat pendidikan dan kesehatan. Angkatan kerja yang terdidik dan terlatih merupakan syarat penting bagi pertumbuhan ekonomi yang berkelanjutan. Semuanya hanya dapat dicapai dengan pendidikan yag baik.

Selain sumber daya manusia,untuk meningkatkan pertumbuhan ekonomi dibutuhkan adanya investasi modal. Investasi dapat dilakukan oleh pemerintah dan swasta. Pemerintah melakukan investasi tanpa mengharap laba tetapi untuk menyediakan barang publik yang menunjang perekonomian.

Sektor kehutanan merupakan sektor yang penting bagi komoditas ekonomi sekaligus menyentuh sisi kebutuhan dasar masyarakat lokal. Pengelolaan sektor kehutanan terutama pada bidang perkebunan rakyat membutuhkan kemitraan yang baik dan serius. Peran pemerintah merupakan fondasi yang penting dalam membuka ruang dan kesempatan petani berusaha di lahan garapannya. Peran pemerintah yang penting dikaji adalah tingkat fokus, fasilitasi, regulasi, dan pengawasannya. Keempat peran tersebut dapat mempengaruhi kinerja pelaksanaan usaha tani perkebunan rakyat yang tinggi integrasi dan produktivitasnya. Terlebih pada kawasan pengelolaan terbatas oleh hak-hak kepemilikan atau manajemen yang lain. Dalam usaha meningkatkan produktivitas dan integrasi tanaman petani, diharapkan petani mampu berinvestasi sehingga mendorong keberdayaannya. Investasi dari pengaruh perkebunan rakyat dapat diamati dari investasi sumberdaya manusia seperti pendidikan dan kesehatan, serta investasi fisik berupa saprotan atau luas lahan dan material lainnya. Investasi sebagai penambah atau pengembang modal juga berkaitan dengan jumlah pengeluaran dan tabungan yang dialokasikan untuk investasi. Peran pemerintah memiliki pengaruh dalam perkebunan rakyat pun dapat pemengaruhi keberdayaan sebagai bentuk output pengaturan oleh kinerja pemerintah daerah. Begitupun dengan pelaksanaan elemen perkebunan rakyat sebagai wujud karya petani dalam berusaha tani memiliki output keberdayaan yang diukur dari pemahaman diri, perencanaan, kekuatan berunding, dan tanggung jawab atas tindakan sendiri. Keberdayaan petani dalam berusahatani juga dapat menndorong investasi baik dalam bidang sumberdaya manusia, fisik, tabungan, dan pengeluaran.

Berdasarkan kerangka pemikiran diatas, maka dapat ditarik hipotesis penelitian yaitu:

1. Tingkat peran pemerintah memiliki pengaruh terhadap tingkat pelaksanaan elemen perkebunan rakyat.

2. Tingkat pelaksanaan elemen perkebunan rakyat memiliki pengaruh terhadap tingkat investasi.

3. Tingkat pelaksanaan elemen perkebunan rakyat memiliki pengaruh terhadap tingkat keberdayaan.

4. Tingkat keberdayaan memiliki pengaruh terhadap tingkat investasi

5. Tingkat peran pemerintah memiliki pengaruh terhadap tingkat keberdayaan.

\section{METODE PENELITIAN}

Penelitian ini menggunakan kombinasi pendekatan kuantitatif dan pendekatan kualitatif. Untuk pendekatan kuantitatif digunakankan metode survei, dimana kuisioner sebagai instrumen utama dalam mengumpulkan data dari responden. Pengertian survei dibatasi pada penelitian yang datanya dikumpulkan dari sampel atas populasi untuk mewakili seluruh populasi (Singarimbun dan Effendi 1989). Pendekatan kuantitatif ini diharapkan dapat menjelaskan elemen perkebunan rakyat, tingkat pengelolaan perkebunan rakyat, serta hubungannya dengan tingkat keberdayaan dan investasi. Pendekatan kualitatif bersifat explanatory research dengan menggunakan teknik wawancara mendalam terhadap informan.

Penelitian ini dilakukan di Desa Sangkima, Kecamatan Sangatta Selatan, Kabupaten Kutai Timur, Provinsi Kalimantan Timur. Pemilihan lokasi dilakukan secara sengaja (purposive) dengan alasan desa dan kecamatan ini merupakan lokasi desa definitif dalam kawasan TN Kutai yang terletak sepanjang poros jalan Bontang-Sangatta yang membelah kawasan TNK. Selain itu, sebanyak 37,64\% lahan desa dikelola menjadi perkebunan. Persentase tersebut merupakan persentase tertinggi pengelolaan lahan di desa. Desa ini mempunyai izin dari Pemerintah Daerah namun tidak ada dari Pemerintah Pusat karena berada di kawasan Taman Nasional. Tanah yang digarap petani dalam berkebun tidak memiliki sertifikat namun hanya segel pemerintah desa atau pinjam-pakai/ ganti-rugi dari penggarap sebelumnya. Penelitian ini berlangsung pada bulan Januari sampai Mei 2015. Untuk proses pengumpulan data di lapangan, peneliti tinggal sementara di Desa Sangkima selama satu bulan.

Penelitian ini melibatkan dua subjek, yaitu responden dan informan. Responden penelitian dipilih dengan mendata keseluruhan rumah tangga Desa Sangkima yang melakukan usaha perkebunan. Sebelum menentukan sampel penelitian, terlebih dahulu disusun kerangka sampling yaitu daftar dari semua unsur sampling dalam populasi. Kerangka sampling dalam penelitian ini adalah petani yang memiliki lahan minimal $1.000 \mathrm{~m}^{2}$, melakukan usaha tani dan berinvestasi dalam lahannya tersebut. Berdasarkan data yang diperoleh dari kantor desa, jumlah petani sesuai kriteria kerangka sampling sebanyak 115 RT, dari populasi 126 RT. Dipilih sampel sebanyak 30 RT dengan simple random sampling. Alasan mengambil 30 responden masing-masing adalah jumlah tersebut sudah mampu merepresentasikan data yang diambil dalam penelitian dan memenuhi jumlah minimum penelitian sejenis. Pemilihan informan dilakukan dengan teknik snowball. Pemilihan informan awal sebagai sumber data telah direncanakan sebelum penelitian dilakukan. Informan awal yang dipilih adalah orang yang dapat membukakan pintu untuk mengenali keseluruhan medan secara luas. Dalam penelitian ini ditentukan informan kunci terlebih dulu yaitu tokoh masyarakat, pihak pemerintah, penduduk asli, petani, dan pihak Balai Taman Nasional Kutai.

Dalam pelaksanaannya, penelitian ini menggabungkan metode penelitian kualitatif dan kuantitatif. Pada tahap awal, digunakan metode kualitatif untuk menemukan hipotesis penelitian dan selanjutnya menggunakan metode kuantitatif untuk menguji hipotesis. Dalam penelitian kuantitatif, teknik pengumpulan data yang utama adalah kuesioner dengan data yang diperoleh berupa data kuantitatif. Untuk memperkuat 
data hasil kuesioner tersebut dilakukan observasi dan wawancara pada responden penelitian maupun di luar responden dimana kedua teknik tersebut merupakan teknik pengumpulan data dalam penelitian kualitatif.

Jenis data yang dikumpulkan dalam penelitian ini adalah data primer dan data sekunder. Data primer didapatkan langsung di lapangan dengan cara observasi, survei, serta wawancara mendalam yang dilakukan langsung kepada responden dan informan. Dalam melakukan survei, setelah responden terpilih melalui teknik pengambilan sampel acak sederhana (simple random sampling). Peneliti mendatangi rumah responden untuk melakukan wawancara berdasarkan pertanyaan atau pernyataan yang ada dalam kuisioner. Adapun data sekunder diperoleh dari dokumen-dokumen yang terkait dengan penelitian ini seperti data profil desa, data kehutanan, data pemerintah serta dokumen lainnya.

Teknik pengolahan dan analisis data dilakukan terhadap data-data baik yang berasal dari temuan kuantitatif dan kualitatif. Data kuantitatif yang terkumpul dianalisis dengan tiga metode analisis, yaitu metode analisis tabel jumlah dengan memanfaatkan Microsoft Excel 2007, tabel ini dibuat agar data dalam jumlah yang banyak dapat disajikan dalam bentuk yang jelas dan baik. Metode analisis yang kedua yaitu metode analisis tabel silang untuk melihat hubungan antar variabel pengaruh dan terpengaruh. Metode analisis ketiga yaitu metode uji statistik regresi untuk menguji pengaruh antar variabel dengan memanfaatkan SPSS 16.0 for Windows yakni analisis regresi. Metode ini dianalisis dengan menganalisis pengaruh variabel-variabel. Melalui uji Cronbach's Alpha diperoleh nilai 0.675; artinya data yang dikumpulkan sudah reliabel. Data kualitatif dianalisis melalui tiga tahapan metode yaitu: Pertama, metode reduksi data, yaitu berupa tahap pemilihan data, pemusatan perhatian, dan penyederhanaan data. Kedua, tahap penyajian data secara deskriptif. Ketiga, menarik kesimpulan sesuai dengan kebutuhan penelitian. Teknik reduksi data dilakukan dengan mengolah catatan harian penelitian ke dalam bentuk manuscript atau tulisan per tematik.

\section{HASIL DAN PEMBAHASAN}

\section{Kondisi Geografis, Topografis, dan Demografis Desa Sangkima}

Secara administratif, Desa Sangkima dalam struktur pemerintahan daerah Kalimantan Timur merupakan desa yang termasuk dalam wilayah Kecamatan Sangatta Selatan Kabupaten Kutai Timur. Secara geografis Desa Sangkima memiliki luas wilayah 37.919,2 hektar. Keadaan topografi desa Sangkima merupakan dataran rendah, dataran tinggi dan pantai dengan ketinggian tanah 0-50 $\mathrm{m}$ di atas permukaan laut (mdpl) dengan suhu udara rata-rata $29^{\circ} \mathrm{C}$. Curah hujan berkisar antara $110 \mathrm{~mm} /$ tahun sampai $114 \mathrm{~mm} /$ tahun. Secara demografi, jumlah penduduk Desa Sangkima berdasarkan data administrasi pemerintahan desa berjumlah 2801 jiwa dengan $807 \mathrm{KK}$. Jumlah enduduk tersebut dapat dirincikan dengan jenis kelamin laki-laki 1426 jiwa (50.91\%) dan perempuan 1.375 jiwa (49.08\%). Dari total jumlah penduduk Desa
Sangkima, yang dapat dikategorikan kelompok rentan dari sisi kesehatan mengingat usia, yaitu penduduk yang berusia $>39$ tahun atau kurang produktif sebanyak banyak $31.42 \%$. Sedangkan usia produktif yaitu antara usia $20-$ 39 tahun sekitar $31.57 \%$ dan untuk usia belum produktif yaitu usia $<20$ tahun sekitar 36.68\%. Kelompok usia $<$ 20 tahun dengan presentase $36.68 \%$ merupakan kategori pelajar. Keberagaman suku penduduk di desa ini karena masuknya penduduk dari berbagai daerah yang identik dengan latar belakang agamanya juga. Misalnya mereka yang berasal dari Sumatera Utara, Tanah Toraja, atau Suku Dayak di Kalimantan biasanya beragama Katolik atau Kristen. Sedangkan pendatang yang berasal dari Jawa atau Sulawesi biasanya beragama Islam. Luasan yang dialokasikan pada perkebunan lebih banyak daripada peruntukan lain (37.64\%). Hal ini yag kemudian membuat perkebunan menjadi potensi yang baik untuk menambah pendapatan keluarga. Perkebunan juga menarik untuk diusahakan karena relatif sesuai dengan keadaan iklim dan keadaan tanah setempat.

\section{Kehidupan Sosial Dusun Lestari Jaya}

Dusun Lestari Jaya yang sering disebut Kampung Jawa ini memiliki 4 RT. Penduduk yang terdaftar tinggal di dusun ini terdiri dari 126 Kepala Keluarga dengan 396 jiwa. Banyak jenis pekerjaan kelompok yang bisa dikerjakan di dusun ini dan salah satu bentuk kerjasama tersebut adalah kesatuan kerja antar suku atau agama. Sekalipun sangat beragam suku dan agama, kondisi ketenangan di dusun ini relatif baik.

Pekerjaan utama warganya merupakan kontraktor baik harian (oplosan) ${ }^{1}$ maupun mereka yang dikontrak penuh. Namun bagi mereka yang pensiun dari Pertamina karena faktor usia, mereka menjadikan kegiatan berkebun sebagai pekerjaan sehari-harinya. Kebun yang mereka garap terletak di beberapa titik tersebar di kawasan Taman Nasional Kutai. Ada kebun yang masih terletak di dusun yang sama, namun ada pula yang berkebun di luar dusun. Rendahnya tingkat aksesibilitas kawasan sangat berpengaruh terhadap kondisi sosial (terbukanya isolasi kawasan, peningkatan kemampuan wawasan, proses interaksi dan lain sebagainya) dan kondisi perekonomian terutama laju pertumbuhan perekonomian di daerah ini. Berdasarkan hasil informasi dari aparatur pemerintahan Desa, pada daerah ini secara umum tingkat pendidikan dominan yang ditempuh oleh masyarakat adalah setingkat pendidikan menengah pertama ke bawah.

\section{Pelaksanaan Elemen Perkebunan Rakyat}

Dalam sistem agroforestri di perkebunan rakyat, ada tiga komponen yang diurus yaitu pohon (tanaman berkayu), tanaman pertanian, dan hewan (ternak termasuk ikan). Pengaturan ketiga komponen itu dilakukan mengikuti ruang dan waktu yang ditetapkan secara arbitrary sesuai dengan keperluan pengelolanya.

1 Oplosan merupakan sebutan warga desa untuk mereka yang bekerja di Pertamina dengan sistem 3 hari shift pagi, 3 hari shift malam, dan 3 hari free. Semua pekerja oplosan tidak menjadikan kontraktor sebagai pekerjaan satu-satunya mengingat banyaknya waktu luang mereka dibanding kontraktor penuh. 
Tabel 1 Jumlah dan persentase tingkat pelaksanaan elemen perkebunan rakyat

\begin{tabular}{lcc}
\hline \multicolumn{1}{c}{ Kategori } & Jumlah & Persentase \\
\hline Tinggi & 3 & 10.0 \\
Sedang & 27 & 90.0 \\
Rendah & 0 & 0.0 \\
Total & 30 & 100.0 \\
\hline
\end{tabular}

Tingkat integrasi yang diukur adalah petak lahan komoditas tertentu yakni tanaman musiman, tahunan, peternakan, perikanan, pertanian lainnya, dan banyaknya komoditas yang tertampung pada luasan tertentu tersebut. Peran luasan sangat penting karena diindikasikan integrasi tinggi terdapat pada lahan yang luas pula. Pengelolaan pada petak lahan tertentu responden cenderung sedang pada luas lahan antara $3000 \mathrm{~m}^{2}$ sampai $45.000 \mathrm{~m}^{2}$ sebanyak $83,3 \%$. Para kontraktor yang bekerja di Pertamina menempati kategori ini. Lahan yang dikelola tidak terlalu luas juga tidak terlalu sempit. Dengan gaji mereka mengembangkan produksi kebun secara perlahan.

Menurut Kariyasa (2005), ciri utama integrasi tanaman ternak adalah adanya sinergisme atau keterkaitan yang saling menguntungkan antara tanaman dan ternak. Petani memanfaatkan kotoran ternak sebagai pupuk organik untuk tanamannya, kemudian memanfaatkan limbah pertanian sebagai pakan ternak. Integrasi komoditas cenderung sedang $(56.7 \%)$ karena dipengaruhi minat pemeliharaan petani dan ketersediaan pasar. Walaupun tingkat integrasi tidak terlalu tinggi atau terlalu rendah, namun pemanfaatan limbah sepertinya tidak terlalu menjadi perhatian. Padahal berdasarkan beberapa penelitian seperti Prabowo et al. (2002), Kulit buah kakao segar merupakan jenis bahan pakan tradisional yang biasa diberikan kepada ternak kambing oleh petani sampai 70\% total pakan.

Desa Sangkima yang dihuni sebagian besar oleh pendatang memiliki persoalan pembentukan entitas sosial multi suku. Menurut Soetarto (2007) persoalan pembentukan entitas sosial multi suku, khususnya pada desa-desa 'baru' yang dibentuk. Dalam konteks desa-desa transmigrasi di Indonesia persoalan tersebut mengikutsertakan pula perihal perbedaan moda produksi (mode of production) yang dibawakan oleh masing-masing suku yang menjadi warga baru. Pada gilirannya perbedaan moda produksi berimplikasi terhadap berhasil tidaknya proses pembentukan entitas sosial baru (komunitas desa) itu sendiri secara sosiologis. Integrasi perkebunan terkait fokus pemerintah didapati memiliki pola tanam petani yang berorientasi pada konservasi (Suku Asli) dan ekonomi oleh suku asli (Suku Jawa). moda produksi masing-masing kelompok suku terwujud dalam pilihan pola tanam bahkan pada luasan yang relatif sama. Kelompok suku asli dengan pola berkelompok tiap komoditas dengan tidak terlalu memperhitungkan tebalnya kanopi dan tutupan tanah. Sementara kelompok suku pendatang khususnya Suku Jawa dengan pola tanam tumpangsari dengan memperhitungkan umur tanaman utama dan telanya kanopi serta tutupan tanah.
Selain nilai integrasi, terdapat pula nilai tingkat produktivitas yang mendukung keberlanjutan usaha tani. Produktivitas merupakan nilai keuntungan $(\mathrm{Rp})$ produksi dibagi luas lahan $\left(\mathrm{m}^{2}\right)$ dan minimnya bencana yang dapat menurunkan produksi. Produktivitas dianggap penting mengingat pengelolaannya yang menyerap banyak input pertanian. Dalam satu luasan tertentu, nilai produktivitas tinggi apabila keuntungan yang didapat banyak pada luasan yang sempit. Produktivitas lahan garapan respondencenderung tinggi yakni $>$ Rp1100/m² $(93.3 \%)$. Produktivitas yang merupakan hasil bagi keuntungan dan petak lahan menjadi pegangan yang kuat meneruskan usaha tani.

Pengukuran dengan menilai tingkat integrasi dan poduktivitas lahan milik responden dapat memahami tingkat pelaksanaan elemen perkebunan rakyat. Berikut tabel jumlah dan persentase tingkat pelaksanaan elemen perkebunan rakyat.

Secara keseluruhan, pelaksanaan elemen perkebunan rakyat terukur cenderung sedang $(90.0 \%)$. Hal ini menandakan penerapan sistem pertanian di lokasi studi tidak terlalu tinggi atau terlaksana dengan maksimal juga tidak terlalu rendah. Hal ini dikarenakan tersebarnya luasan kebun yang bisa dikelola sehingga masyarakat dapat berkebun sesuai kemampuannya. Luasan perkebunan tersebut kemudian mampu menunjang produktivitas lahan walau digantinya tumbuhan hutan dengan tanaman perkebunan. Integrasi dipandang menjadi hal yang baik diterapkan dengan memperhatikan umur tanaman dan kanopinya.

\section{Peran Pemerintah Dalam Perkebunan Rakyat}

Banyak peran pemerintah yang dapat terlihat dalam pengembangan perkebunan rakyat antara lain fokus pengelolaan perkebunan rakyat, peran fasilitasi input pertanian, melakukan regulasi pengelolaan perkebunan rakyat, dan pengawasan pengelolaannya. Kefokusan petani dalam mengelola perkebunannya dapat diperhatikan dari tujuan dan orientasi petani dalam mengelola hutan. Menilai fokus pemerintah dapat pula dilakukan dengan meninjau keadaan di lapang dengan mengobservasi penerapannya di lapang. Fokus tersebut dapat berupa fokus untuk konservasi, kegiatan ekonomi, maupun kolaborasi dari konservasi dan kegiatan ekonomi. Pada pengukuran kepentingan pengelolaan perkebunan petani, kepentingan petani mengelola perkebunan mereka selain untuk kepentingan ekonomi, juga untuk kegiatan konservasi (83.3\%). Dalam perjalanan perkembangan perkebunan rakyat, masyarakat mengelolanya dengan berbagai kepentingan. Beberapa diantaranya mengerjakan dengan merasa bertanggungjawab dengan menyatakan kepentingan untuk kegiatan ekonomi dan konservasi. Ada pula yang meyatakan hanya untuk kegiatan ekonomi, atau tidak keduanya. bahwa responden memiliki tingkat fokus yang tinggi dalam pengelolaan perkebunan rakyat berupa kolaborasi kegiatan ekonomi dan konservasi yakni 63.7\%, walaupun terdapat responden yang hanya berorientasikan kegiatan ekonomi dalam kegiatan berkebunnya (36.7\%). Bagi mereka yang berorientasi pada kegiatan ekonomi dan konservasi, mereka mengusahakan agar tidak terjadi 
- Sosialisasi

- Pengetahuan pribadi

- Media

- Tidak tahu

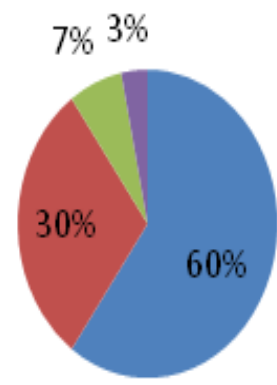

Gambar 2 Grafik sumber informasi pencegahan pelanggaran aturan

pembukaan lahan yang terlalu ekstrim yakni lebih dari $50 \mathrm{~m}^{2}$. Sistem tumpang sari sering diterapkan karena selain untuk meningkatkan produksi, juga untuk menambah tutupan vegetasi. Penyuluhan yang diberikan oleh penyuluh pun dapat memicu peningkatan fokus ekonomi ini.

Tingkat fasilitasi dapat dilihat dari kemampuan fasilitator pemerintah menyediakan berbagai input perkebunan dan perlengkapannya. Pada tingkat fasilitasi, pengukuran yang dilakukan adalah jumlah pemberian benih, lahan, pupuk, pestisida, insektisida, pemasaran, modal, dan penyuluhan. Selain jumlah, diukur pula persepsi mereka terhadap bantuan serta jumlahnya tersebut. Pada tingkat fasilitasi, fasilitasi terhadap input perkebunan cenderung rendah yakni $76.7 \%$. Bantuan yang didapat sebagian besar dalam bentuk benih oleh $50 \%$ responden. Bantuan yang pernah dirasakan oleh satu responden yang berbeda-beda adalah lahan, pupuk dalam bentuk subsidi, pestisda, insektisida, dan penyuluhan. Sedangkan bantuan yang tidak pernah diterima responden adalah jalur pemasaran dan modal. Input pertanian yang didapat responden biasanya mampu dibeli sendiri. Sedangkan responden yag berada di kategori tinggi dan sedang adalah mereka yang pernah atau sering mengajukan proposal ke Dinas Pertanian atau Pemerintah Desa.

Pada tingkat regulasi, regulasi pemerintah dapat pula ditinjau dari tingkatan norma. Tingkatan internalisasi norma-norma dapat dinilai dengan menggunakan tingkatan norma yang melembaga berdasarkan kuat atau lemahnya ikatan yang dimiliki oleh norma tersebut. Tingkatan norma tersebut diukur berdasarkan sanksi moral dan sanksi masyarakat atas pelanggaran yang dilakukan. Kontrol sosial bertujuan untuk mencapai keserasian antara stabilitas dengan perubahanperubahan dalam masyarakat. Suatu sistem kontrol sosial bertujuan untuk mencapai keadaan damai melalui keserasian antara kepastian dengan keadilan/kesebandingan. Dari tugas pokok dan fungsi Taman Nasional Kutai berdasarkan Peraturan Menteri Kehutanan Nomor P.03/MenhutII/2007, terdapat fungsi perlindungan, pengamanan dan penanggulangan kebakaran hutan TN Kutai. Namun dalam pengawasan di Desa Sangkima khususnya lahan garapan responden, tingkat regulasi cenderung sedang $(76.7 \%)$. Hal ini dapat menjadi pengawasan yang lumayan baik dari segi responden. Namun pegaturan dalam usaha perkebunan rakyat yang mereka kerjakan tidak sepenuhnya diketahui
Tabel 2 Jumlah dan persentase peran pemerintah

\begin{tabular}{lcc}
\hline \multicolumn{1}{c}{ Kategori } & Jumlah & Persentase \\
\hline Tinggi & 1 & 3.3 \\
Sedang & 27 & 90.0 \\
Rendah & 2 & 6.7 \\
Total & 30 & 100.0 \\
\hline
\end{tabular}

dari pemerintah yang berkonsentrasi menegakkan peraturan. Peraturan yang banyak diketahui responden secara umum adalah tidak boleh membakar lahan garapan untuk mencegah perambatan api terlalu luas.

Peraturan ini diketahui lewat sosialisasi (60\%), pengetahuan pribadi $(30 \%)$, media cetak maupun elektronik (6.7\%). Sebanyak $60 \%$ terkadang melakukan pelanggaran terhadap peraturan yang mereka ketahui. Terlebih pada peraturan dilarang membakar lahan, sebagian besar responden pasti melakukan pembakaran saat awal merintis kebunnya.

Dalam peraturan yang dipahami masyarakat pula, tertanam nilai-nilai yang mendukung cara persuasif tersebut yakni ketaatan (66.7\%) dan kepedulian (30\%). Responden memandang nilai ketaatan harus tertanam dalam kepribadian petani agar keseimbangan ekosistem masih terjaga. Nilai ketaatan harus terlaksana oleh semua petani agar bertanggungawab dalam mengelola lahannya. Sedangkan nilai kepedulian dipandang responden penting diaplikasikan agar menjaga bersama kapasitas lahan satu sama lain. Nilai-nilai ini terkadang diindahkan (konformitas) oleh $96.7 \%$ responden namun juga terkadang tidak jika terlalu berorientasi ekonomi (deviasi) oleh $3.3 \%$ responden. Hasil pengukuran peran pemerintah pada perkebunan rakyat melalui pengukuran tingkat fokus, tingkat fasilitasi, tingkat regulasi, dan tingkat pengawasan adalah sebagai berikut.

Menurut responden, pemerintah sebenarnya kurang berperan banyak terhadap usaha perkebunan mereka kecuali bagi mereka yang punya posisi yang baik di bidang pertanian. Posisi sebagai bagian dari kelompok tani ternyata lumayan membantu usaha tani. Kategori sedang dinilai responden akan peran pemerintah pada perkebunan rakyat $(90.0 \%)$. Namun tidak semua hal pengukuran merupakan hasil kerja langsung pemerintah kepada petani. Karena ada beberapa nilai yang tertanam bagi responden merupakan aspek tidak langung yang diterima dari pemerintah.

\section{Pola Investasi}

Analisa pola investasi akan dilakukan dengan menilai investasi sumberdaya manusia, investasi fisik, tabungan, dan pengeluaran. Kualitas sumber daya manusia sangat diperukan dalam peningkatan kualitas faktor produksi. Kualitas faktor produksi sumber daya manusia sangat dipengaruhi oleh tingkat pendidikan dan kesehatan. Angkatan kerja yang terdidik dan terlatih merupakan syarat penting bagi pertumbuhan ekonomi yang berkelanjutan. Investasi untuk pendidikan, jumlah tinggi (penting) yang paling banyak yakni $70 \%$ adalah pada usaha memfasilitasi anak agar berpendidikan sampai tingkat Perguruan Tinggi. 
Tabel 3 Jumlah dan persentase berdasarkan tingkat investasi

\begin{tabular}{lcc}
\hline \multicolumn{1}{c}{ Kategori } & Jumlah & Persentase \\
\hline Tinggi & 13 & 43.3 \\
Sedang & 10 & 33.3 \\
Rendah & 7 & 23.3 \\
Total & 30 & 100.0 \\
\hline
\end{tabular}

Sedangkan jumlah rendah (tidak penting) yang paling banyak sebesar $60 \%$ adalah pada pandangan pendidikan anggota keluarga setelah bekerja diharapkan menambah kekuatan ekonomi keluarga. Pada investasi berupa tingkat kesehatan, usaha kesehatan memiliki jumlah tinggi (penting) yang lebih banyak adalah penanggulangan penyakit (100\%), usaha kesehatan (96.7\%), dan kesehatan untuk penghasilan (93.3\%). Dari responden yang diteliti, sebagian besar sudah memiliki kartu BPJS kesehatan dan memperhatikan dengan serius kesehatan keluarga.

Investasi fisik (physical investment) adalah semua pengeluaran yang dapat menciptakan modal baru atau meningkatkan stok barang modal. Investasi fisik dapat berupa barang fisik seperti luas lahan, sarana pertanian, atau materi-materi pendukung usaha pertanian. Investasi berupa pengeluaran yag dapat menciptakan modal baru atau meningkatkan stok barang modal cenderung rendah karena ketersediaan sarana usaha tani sudah dilengkapi oleh petani. Sedangkan luas lahan, tidak direncanakan akan memperluas areal pengelolaan dalam waktu dekat dengan lahan dengan membayar uang ganti rugi. Terutama bagi responden yang bekerja sebagai kontraktor, mereka merasa luas lahan 1-3 ha sudah sangat cukup untuk dikelola karena keterbatasan waktu dan tenaga mereka.

Tabungan merupakan uang simpanan yang sengaja dialokasikan untuk waktu berikutnya dikurangi jumlah utang dari waktu mengadakan transaksi utang hingga tepat waktu penelitian. Dari hasil penelitian alokasi tabungan cenderung tinggi yakni $73.3 \%$. Hal ini dikarenakan banyaknya rencana masa depan untuk pendidikan anak dan rencana peningkatan produksi usaha tani. Tabungan inilah yang kemudian digunakan untuk berinvestasi baik untuk SDM maupun fisik.

Pengeluaran adalah jumlah uang yang dikeluarkan untuk kebutuhan rumah tangga baik dari aspek pangan maupun nonpangan. Beberapa persen dari pengeluaran akan dialokasikan untuk investasi fisik maupun SDM. Responden memiliki pengeluaran yang cenderung sedang (76.7\%). Pengeluaran yang sedang berarti kebutuhan RT tidak terlalu tinggi, dengan keadaan anak masih bersekolah dan pengelolaan lahan tidak terlalu mahal. Berdasarkan pengukuran tingkat investasi dari tingkat investasi sumberdaya manusia, investasi fisik, tabungan, dan pengeluaran, berikut tabel jumlahnya.

Dari tingkat investasi responden, kategori yang lebih banyak adalah indikator tinggi sebanyak $43.3 \%$ responden. Investasi yang tinggi memang diakui oleh para responden dari beberapa aspek mulai dari materi hingga sumberdaya manusia. Khusus pada bidang usaha tani, perkebunan mempengaruhi bidang yang lainnya. Apalagi responden sengaja menanam tanaman keras atau tahunan yang dapat menghasilkan berkali-kali. Tanaman tahunan menjadi pilihan yang banyak dipilih petani daripada yang musiman. Selain karena lebih mudah merawat, waktu yang tercurah untuk tanaman musiman juga tidak terlalu banyak.

\section{Tingkat Keberdayaan}

Pemberdayaan adalah proses penguatan agar seseorang atau sekelompok masyarakat dapat berpartisipasi dalam mengkontrol dan mempengaruhi jalannya kekuasaan dan lembaga-lembaga yang terkait dan mempengaruhi kehidupan seseorang atau masyarakat. Ciri-ciri masyarakat yang telah berdaya menurut Sumarjo dkk (2004) adalah sebagai berikut: a) mampu memahami diri dan potensinya, b) mampu merencanakan (mengantisipasi kondisi perubahan kedepan) dan mengarahkan dirinya sendiri, c) memiliki kekuatan untuk berunding dan bekerjasama secara saling menguntungkan dengan "bargaining power" yang memadai, d) bertanggung jawab atas tindakan sendiri.

Pemahaman diri dan potensinya secara holistik merupakan hal fundamental bagi mereka yang ingin berusaha mendapatkan hasil dari pekerjaannya. Dalam hal memahami diri dan potensinya dalam pengetahuan pengeluaran keluarga, pendapatan untuk menutupi pengeluaran, pendapatan khusus pertanian, komoditas nilai jual tinggi, kebutuhan dibantu orang lain, dan keuntungan petani, responden memiliki pemahaman cenderung kategori sedang $(90.0 \%)$.

Pada ciri tingkat perencanaan, pengukuran dilakukan dari kemampuan merencanakan panen masing-masing komoditas, harga di pasar, rencana tanam selanjutnya, perkiraan harga sedang tinggi/rendah, rancang pendapatan usaha tani untuk pengeluaran keluarga, dan rencana alternatif jika gagal panen. Dalam hal perencanaan, responden cenderung berada pada kategori sedang (76.7\%). Responden tidak terlalu menguasai perencanaan bidang pertanian juga mengalokasikan usaha tani untuk pendapatan keluarga. Namun juga tidak terlalu sulit untuk merencanakan hal-hal mudah dalam berkebun.

Tidak memiliki institusi yang formal untuk berbagi pengetahuan dan fasilitas pertanian tidak juga menjadi hal yang menurunkan produsi dan produktivitas lahan petani. Pengukuran kekuatan berunding dan bekerjasama secara saling menguntungkan dengan "bargaining power" yang memadai dilakukan dengan mengukur kemampuan saling menguntungkan. Pengukuran yang dilakukan adalah kemapuan menyatakan kehendak dalam masalah usaha tani, kemampuan dipercayai, bekerjasama, saling menguntungkan, bertukar pikiran dalam meperkuat usaha tani, dan mengatasi gagal panen. Kekuatan berunding

Tabel 4 Jumlah dan persentase tingkat keberdayaan

\begin{tabular}{lcc}
\hline \multicolumn{1}{c}{ Kategori } & Jumlah & Persentase \\
\hline Tinggi & 3 & 10.0 \\
Sedang & 27 & 90.0 \\
Rendah & 0 & 0.0 \\
Total & 30 & 100.0 \\
\hline
\end{tabular}


Tabel 5 Tabulasi silang tingkat peran pemerintah terhadap tingkat pelaksanaan perkebunan rakyat

\begin{tabular}{|c|c|c|c|c|c|c|c|}
\hline \multirow{3}{*}{$\begin{array}{c}\text { Tingkat } \\
\text { peran } \\
\text { Pemerintah }\end{array}$} & \multicolumn{7}{|c|}{$\begin{array}{c}\text { Tingkat Pelaksanaan Perkebunan } \\
\text { Rakyat }\end{array}$} \\
\hline & \multicolumn{2}{|c|}{ Rendah } & \multicolumn{2}{|c|}{ Sedang } & \multicolumn{2}{|c|}{ Tinggi } & \multirow{2}{*}{$\begin{array}{l}\text { To- } \\
\text { tal }\end{array}$} \\
\hline & $\mathbf{n}$ & $\%$ & $\mathbf{n}$ & $\%$ & $\mathbf{n}$ & $\%$ & \\
\hline Кenuan & 1 & 100 & 0 & 0 & 0 & 0 & 1 \\
\hline Seda & 9 & 33.4 & 16 & 59.3 & 2 & 7.4 & 27 \\
\hline Tinggi & 0 & 0 & 1 & 50 & 1 & 50 & 2 \\
\hline
\end{tabular}

ternyata merupakan hal yang mudah bagi petani dan petani lain tidak menutup diri untuk berunding pula. Kekuatan sosial di desa dinyatakan cukup baik dengan tingkat persaingan yang rendah dari usaha pertanian. Darik kekuatan berunding, responden cenderung berkemampuan tinggi untuk berunding $(63.3 \%)$.

Bentuk tanggungjawab atas tindakan sendiri dapat dinilai dari kesiapan responden akan perlakuannya pada usaha taninya dan kemampuannya mengambil resiko dengan beberapa pertimbangan. Selain itu, tanggung jawab yang baik petani dapat dilihat dari kemampuannya meyelesaikan masalah internal dan eksternal perkebunannya. Pengukuran yang dilakukan adalah menilai kesiapan resiko keputusan yang diambil, menyelesaikan sengketa lahan, kesiapan harga yang jatuh di pasar, dan pertumbuhan benih yang tidak sesuai dengan yang diharapkan. Dari pengukuran tanggungjawab cenderung tinggi terhadap tindakan sendiri (76.7\%). Responden dinilai memiliki toleransi yang baik dan kesiapan mengambil keputusan usaha tani sendiri. Namun, responden juga dinilai bukan sepenuhnya bertanggungjawab namun karena ada beberapa responden yang kurang serius dalam usaha taninya. Alasannya, dalam pembukaan kebun, petani tidak perlu membayar uang sewa tanah. Bibit tanaman pun diperoleh dari hasil semai sendiri. Penambahan unsur hara lain hanya terkadang saja dilakukan tanpa rasa rugi. Berdasarkan pengukuran keberdayaan dari pemahaman diri, perencanaan, kekuatan berunding, hingga tanggung jawab akan tindakan sendiri, berikut tabel jumlahnya.

Pengukuran keberdayaan pada responden menunjukkan tingkat yang cenderung sedang $(90 \%)$. Indikator penyusun tingkat keberdayaan yang paling tinggi adalah ordinal tanggung jawab. Hal ini dikarenakan pada ordinal tanggung jawab menyatakan kesiapan atas tindakan mereka sendiri. Responden mampu menanggung resiko usaha tani mereka

Tabel 6 Tabulasi silang tingkat pelaksanaan perkebunan rakyat terhadap tingkat investasi

\begin{tabular}{|c|c|c|c|c|c|c|c|}
\hline \multirow{3}{*}{$\begin{array}{c}\text { Tingkat } \\
\text { pelaksanaan } \\
\text { perkebunan } \\
\text { rakyat }\end{array}$} & \multicolumn{7}{|c|}{ Tingkat investasi } \\
\hline & \multicolumn{2}{|c|}{ Rendah } & \multicolumn{2}{|c|}{ Sedang } & \multicolumn{2}{|c|}{ Tinggi } & \multirow{2}{*}{$\begin{array}{l}\text { To- } \\
\text { tal }\end{array}$} \\
\hline & $\mathbf{n}$ & $\%$ & $\mathbf{n}$ & $\%$ & $\mathbf{n}$ & $\%$ & \\
\hline Rendah & 4 & 40 & 3 & 30 & 3 & 30 & 10 \\
\hline Sedang & 3 & 17.7 & 5 & 29.4 & 9 & 52.9 & 17 \\
\hline Tinggi & 0 & 0 & 2 & 66.7 & 1 & 33.3 & 3 \\
\hline
\end{tabular}

Tabel 7 Tabulasi silang tingkat keberdayaan terhadap tingkat investasi

\begin{tabular}{|c|c|c|c|c|c|c|c|}
\hline \multirow{3}{*}{$\begin{array}{c}\text { Tingkat } \\
\text { keber- } \\
\text { dayaan }\end{array}$} & \multicolumn{7}{|c|}{ Tingkat investasi } \\
\hline & \multicolumn{2}{|c|}{ Rendah } & \multicolumn{2}{|c|}{ Sedang } & \multicolumn{2}{|c|}{ Tinggi } & \multirow{2}{*}{$\begin{array}{l}\text { To- }- \\
\text { tal }\end{array}$} \\
\hline & $\mathbf{n}$ & $\%$ & $\mathbf{n}$ & $\%$ & $\mathbf{n}$ & $\%$ & \\
\hline Rendah & 0 & 0 & 0 & 0 & 0 & 0 & 0 \\
\hline Sedang & 0 & 0 & 16 & 59.3 & 11 & 40.7 & 27 \\
\hline Tinggi & 0 & 0 & 0 & 0 & 3 & 100 & 3 \\
\hline
\end{tabular}

karena jika rugi pada salah satu komoditas dapat ditutupi produksi komoditas lain. Selain itu pada masalah sengketa lahan usaha tani, mereka siap untuk menyelesaikan dengan sama-sama menguntungkan dan diharapkan masalah dapat diselesaikan berdua dengan pihak yang bersengketa saja.

\section{Peranan Perkebunan Rakyat Pada Investasi Dan Keberdayaan}

\section{Pengaruh Peran Pemerintah terhadap Tingkat Pelaksanaan Elemen Perkebunan Rakyat}

Perkebunan rakyat tertentu masih dibawah kuasa pemerintah pusat seperti TNK, maka perlu peran pemerintah yang serius terhadap pengelolaannya, juga untuk mencegah perambahan lebih lanjut. Peran pemerintah yang dapat diandalkan adalah pengawasan, regulasi, fokus pengelolaan, dan fasilitasi. Sedangkan dalam perkebunan rakyat sendiri untuk mendukung usaha tani diperlukan integrasi komoditas dalam luasan lahan tertentu dan produktivitas yang tinggi. Hubungan antara peran perkebunan rakyat terhadap pelaksanaan elemennya dapat dilihat pada tabulasi silang berikut.

Sesuai dengan hipotesis penelitian ini seharusnya semakin tinggi tingkat peran pemerintah maka semakin tinggi pelaksanaan elemen perkebunan rakyat. Pada tabulasi silang, peran pemerintah rendah maka pelaksanaan perkebunan rakyat juga rendah mutlak $(100 \%)$ dan saat tingkat peran pemerintah tinggi, persentasi pelaksanaan perkebunan rakyat juga tinggi (50\%). Dari kesesuaian ini, dapat dipahami bahwa tingkat peran pemerintah mempengaruhi tingkat pelaksanaan elemen perkebunan rakyat.

H0 dari uji regresi ini adalah tidak ada pengaruh peran pemerintah terhadap produktivitas lahan. Walaupun integrasi tanaman dipengaruhi oleh peran pemerintah, namun tidak demikian dengan produktivitas. Pengukuran integrasi lahan

Tabel 8 Tabulasi silang tingkat peran pemerintah terhadap tingkat keberdayaan

\begin{tabular}{lrrrrrrrr}
\hline \multirow{2}{*}{$\begin{array}{c}\text { Tingkat } \\
\text { peran } \\
\text { pemerintah }\end{array}$} & \multicolumn{6}{c}{ Tingkat keberdayaan } \\
\cline { 2 - 7 } & Rendah & \multicolumn{1}{c}{ Sedang } & \multicolumn{1}{c}{ Tinggi } & T o - \\
\cline { 2 - 7 } & $\mathbf{n}$ & $\%$ & \multicolumn{1}{c}{$\mathbf{n}$} & $\%$ & $\mathbf{n}$ & $\%$ & tal \\
\hline Rendah & 0 & 0 & 1 & 100 & 0 & 0 & 1 \\
Sedang & 0 & 0 & 25 & 92.6 & 2 & 7.4 & 27 \\
Tinggi & 0 & 0 & 1 & 50 & 1 & 50 & 2 \\
\hline
\end{tabular}


Tabel 9 Hasil uji statistik analisis regresi linear pengaruh tingkat peran pemerintah terhadap tingkat keberdayaan

Model Summary

\begin{tabular}{lrrr}
\hline$R$ & R Square & $\begin{array}{c}\text { Adjusted R } \\
\text { Square }\end{array}$ & $\begin{array}{c}\text { Std. Error of the } \\
\text { Estimate }\end{array}$ \\
\hline $.391^{\mathrm{a}}$ & .153 & .017 & 5.40883 \\
\hline
\end{tabular}

\begin{tabular}{lcrccc}
\multicolumn{8}{c}{ ANOVA $^{\mathrm{b}}$} \\
\hline Model & Sum of & df & Mean & \multirow{2}{*}{ S Sig. } \\
& Squares & \multicolumn{1}{c}{ Square } & F & Sig \\
\hline Regress-ion & 131.814 & 4 & 32.954 & 1.126 & $.367^{\mathrm{a}}$ \\
Residual & 731.386 & 25 & 29.255 & & \\
\hline Total & 863.200 & 29 & & & \\
\hline
\end{tabular}

dapat dilakukan walaupun komoditas masih sangat muda dan belum menghasilkan.

\section{Pengaruh Tingkat Pelaksanaan Elemen Perkebunan Rakyat terhadap Tingkat Investasi}

Peran Perkebunan rakyat dapat terlaksana mengingat kemampuannya berproduktivitas tinggi karena terintegrasi tanaman lainya. Produktivitas dalam integrasi tersebut kemudian memicu investasi baik dalam investasi SDM, fisik, pengeluaran, bahkan tabungan. Berikut hubungan pelaksanaan perkebunan rakyat dengan tingkat investasi.

Sesuai dengan hipotesis penelitian ini seharusnya semakin tinggi tingkat pelaksanaan perkebunan rakyat maka semakin tinggi tingkat investasi. Pada tabulasi silang, tingkat pelaksaan perkebunan rakyat rendah maka pelaksanaan perkebunan rakyat rendahmencapai $40 \%$ dan saat pelaksanaan perkebunan rakyat tinggi, persentasi tingkat investasi tidak tinggi hanya mencaai $33.3 \%$. Sebaliknya pada pelaksanaan tingkat tinggi, investasi cenderung sedang $66.7 \%$. Dari ketidaksesuaian ini, dapat dipahami bahwa tingkat pelaksanaan perkebunan rakyat tidak mempengaruhi tingkat investasi. Investasi dapat dipenuhi dari pengeluaran akan kebutuhan sehari-hari. Selain itu pemasukan dari gaji bulanan tidak juga mampu berinvestasi besar pada perkebunan karena dapat habis untuk kebutuhan rumah tangga.

\section{Pengaruh Tingkat Keberdayaan terhadap Tingkat Investasi}

Perkebunan rakyat turut mendorong keberdayaan petani yang mengusahakannya dan dapat pula mendorong petani untuk menambah atau mengembangkan modalnya baik fisik ataupun abstrak. Peningkatan stok modal tersebut sering mengindikasikan peningkatan keberdayaan pula. Pengaruh tingkat keberdayaan dengan tingkat keberdayaan dapat dilihat sebagai berikut.

Sesuai dengan hipotesis penelitian ini seharusnya semakin tinggi tingkat keberdayaan maka semakin tinggi pula tingkat investasi. Kondisi seperti ini berlaku pada tingkat keberdayaan sedang dan tinggi. Sedangkan pada tingkat keberdayaan rendah, mulai dari investasi rendah hingga tinggi bernilai $0 \%$. Dari kesesuaian ini, dapat dipahami bahwa tingkat keberdayaan mempengaruhi tingkat investasi petani pula.

Dari temuan lapang, memang didapati mereka yang berinvetasi tinggi juga memiliki nilai keberdayaan yang tinggi pula. Berdasarkan tingkat investasi, pengukuran dibagi pada tingkat investasi sumberdaya manusia dan investasi fisik. Dari tingkat investasi sumber daya manusia, responden menyatakan bahwa pendidikan sangat perlu. Apalagi tidak ada lagi halangan ekonomi yang terlalu signifkan untuk tingkat pendidikan mengingat pendapatan yang relatif tinggi dalam bidang pekerjaan responden.

\section{Pengaruh Tingkat Peran Pemerintah terhadap Tingkat Keberdayaan}

Peran pemerintah dalam mengelola hutan baik dalam hal mengatur fokus, pengawasan, regulasi, hingga fasilitasi juga dipandang mampu membentuk keberdayaan petani. Keberdayaan tersebut, menurut Sumardjo et al. (2004) dapat dilhat dengan ciri sebagai berikut : a) mampu memahami diri dan potensinya, b) mampu merencanakan (mengantisipasi kondisi perubahan kedepan) dan mengarahkan dirinya sendiri, c) memiliki kekuatan untuk berunding dan bekerjasama secara saling menguntungkan dengan "bargaining power" yang memadai, d) bertanggung jawab atas tindakan sendiri. Pengaruh peran pemerintah dengan tingkat keberdayaan dapat dilihat sebagai berikut.

Sesuai dengan hipotesis penelitian ini seharusnya semakin tinggi tingkat peran pemerintah maka semakin tinggi tingkat keberdayaan. Pada tabulasi silang, tingkat peran pemerintah rendah maka tingkat keberdayaan $0 \%$ dan saat peran pemerintah tinggi, persentasi tingkat keberdayaan tidak tinggi hanya mencaai $50 \%$. Dari ketidaksesuaian ini, dapat dipahami bahwa tingkat peran pemerintah tidak mempengaruhi tingkat keberdayaan.

Pada uji regresi yakni uji t, maka dapat dilihat nilai sig. Karena nilai $\mathrm{F}$ hitung sebesar 1.126 yang memiliki tingkat sig 0.367 , lebih besar dari 5\% maka dapat disimpulkan bahwa semua variabel bebas, yakni peran pemerintah bersama-sama tidak berpengaruh signifikan terhadap variabel terikat (tingkat keberdayaan) dan hipotesis ditolak. Nilai R square sebesar 0.153 memiliki arti bahwa kemampuan variabel bebas untuk menjelaskan besarnya variasi dalam variabel terikat adalah sebesar 15.3\%. Variabel lain yang bisa dijelaskan melalui keberdayaan dari pemahaman diri dari manajemen mandiri keluarga dan bantuan kerabat terdekat, bukan dari pemerintah. Pengetahuan komoditas tanam yang lebih menguntungkan juga merupakan pengetahuan umum yang bisa dipelajari secara luas. Dalam hal perencanaan fasilitasi yang kurang dari pemerintah membuat perencanaan dapat diatur sendiri oleh petani sembari belajar dari pengalaman petani lain. Dari kekuatan berunding, kekuatan sosial memegang peranan penting sehingga kemampuan bergaining power dapat memadai. Terakhir dari segi tanggung jawab, karena banyak ketidakpastian lahan dan harga yang diserahkan pada pasar, petani siap atas tindakannya sendiri. 


\section{KESIMPULAN DAN SARAN}

\section{Kesimpulan}

Peran pemerintah terhadap perkebunan rakyat diukur berdasarkan tingkat fokus, fasilitasi, regulasi, dan pengawasan dalam mendorong investasi tergolong sedang (90.0\%). Tingkat sedang pada peran pemerintah berpengaruh pada tingkat integrasi perkebunan rakyat namun tidak berpengaruh pada tingakat produktivitas. Pola investasi responden pada tingkat investasi fisik yang dinilai dapat menambah atau mengembangkan modal sebelumnya rendah, investasi SDM dan pengeluaran sedang, tabungan tinggi. Pelaksanaan dari perkebunan rakyat tidak berpegaruh pada tingkat investasi karena untuk mengalokasikan investasi, petani tidak terlalu kuat melaksanakan usaha taninya. Tingkat keberdayaan yang diukur berdasarkan tingkat pemahaman diri, perencanaan, kemampuan berunding, dan tanggung jawab tergolong sedang $(90.0 \%)$. Tingkat pelaksanaan elemen perkebunan rakyat tidak berpengaruh nyata pada tingkat keberdayaan. Hal ini terjadikarena keberdayaan yang diukur berdasarkan empat indikator tersebut tidak berasal dari aktivitas usaha tani. Petani yang mengelola lahan tersebut juga tidak terlalu menguasi beberapa aspek pengukuran keberdayaan dari bidang pertanian terutama pada usaha alternatif mengurangi kerugian saat atau akan gagal panen. Tingkat keberdayaan berpengaruh pada tingkat investasi. Dari temuan lapang, petani yang berinvetasi tinggi juga memiliki nilai keberdayaan yang tinggi pula. Apalagi tidak ada lagi halangan ekonomi yang terlalu signifkan untuk tingkat pendidikan mengingat pendapatan yang relatif tinggi dalam bidang pekerjaan responden. Peran pemerintah tidak berpengaruh nyata pada tingkat keberdayaan dengan nilai $R$ square 0.153 . Nilai $R$ square sebesar 0.153 memiliki arti bahwa kemampuan variabel bebas untuk menjelaskan besarnya variasi dalam variabel terikat adalah sebesar $15.3 \%$ sisanya dijelaskan variabel lain. Variabel lain tersebut antara lain manajemen mandiri keluarga, bantuan kerabat terdekat. Keberdayaan petani juga dapat mendorong investasi yang baik untuk kemapanan SDM maupun objek pertanian itu sendiri.

Peran perkebunan sebenarnya memiliki pengaruh yang luas dan kompleks terhadap ketatanegaraan, sosial, dan ekonomi, terutama bagi perkebunan yang berada di dalam wilayah taman nasional. Peran pemerintah sebaiknya dimaksimalkan terutama pada tingkat pengawasan untuk mencegah konflik dengan TNK atau kerusakan lingkungan, dari lingkup studi, perlu diteliti kontribusi pemerintah pusat atau kolaborasinya dengan pemerintah daerah untuk meningkatkan investasi dan keberdayaan masyarakat yang arif. Selain itu, perlu juga penelitian lebih lanjut dengan inventarisasi investasi jang pendek hingga menengah untuk mengetahi keberdayaan yang sesungguhnya dari para petani.

\section{Saran}

Peran perkebunan sebenarnya memiliki pengaruh yang luas dan kompleks terhadap ketatanegaraan, sosial, dan ekonomi, terutama bagi perkebunan yang berada di dalam wilayah taman nasional. Peran pemerintah sebaiknya dimaksimalkan terutama pada tingkat pengawasan untuk mencegah konflik dengan TNK atau kerusakan lingkungan, dari lingkup studi, perlu diteliti kontribusi pemerintah pusat atau kolaborasinya dengan pemerintah daerah untuk meningkatkan investasi dan keberdayaan masyarakat yang arif. Selain itu, perlu juga penelitian lebih lanjut dengan inventarisasi investasi jang pendek hingga menengah untuk mengetahi keberdayaan yang sesungguhnya dari para petani.

\section{DAFTAR PUSTAKA}

S. 2006. Konservasi tanah dan air. Bogor (ID): IPB Press. Budiadi, Suryanto P, Sabarnudin S. 2012. Pembaharuan paradigma agroforestri Indonesia seiring meningkatnya isu kerusakan lingkungan dan sustainable livelihood. Yogyakarta ( I D ). Seminar nasional Agroforestri III Mei 2012.

[CIFOR] Center for International Forestry Research . 2003. Perhutanan sosial. Warta Kebijakan. [internet]. [diacu 2014 September 19]; 9(01): 1-6. Tersedia dari: www.cifor.org/acm/download/pub/wk/warta09.pdf.

Fajari OA. 2002. Efektivitas program hutan kemasyarakatan dalam meningkatkan kesejahteraan masyarakat melalui redistribusi lahan [tesis]. Bogor (ID). Sekolah Pascasarjana. Institut Pertanian Bogor.

Irawanti S, Dwiprabowo H, Suka AP. 2012. Manfaat ekonomi dan peluang pengembangan hutan rakyat sengon di Kabupaten Pati. Jurnal Peneitian Sosial Ekonomi Kehutanan. [internet]. [diacu 2014 September 19]; 9(3): 126-139. Tersedia dari: http://ejournal.forda-mof.org/ejournal-

Irawanti S, Dwiprabowo H, Suka AP. 2012. Peranan kayu dan hasil bukan kayu dari hutan rakyat pada pemilikan lahan sempit: Kasus Kabupaten Pati. Jurnal Penelitian Sosial Ekonomi Kehutanan. [internet]. [diacu 2014 September 19]; 9(3):113125. Terdapat dari: http://ejournal.fordamof.org/ejournal-litbang/index.php/JPSE/article/ vie

Kariyasa Ketut. 2005. Sistem integrasi tanaman-ternak dalam perspektif reorientasi kebijakan subsidi pupuk dan peningkatan pendapatan petani. Analisis Kebijakan Pertanian [internet]. [diacu 2014 September 19]: 3(1):1-13. Terdapat dari :http://art03-1d.pdf

Kolopaking LM. et al. 2003. Sosiologi umum. Bogor. Bagian ilmu-ilmu sosial komunikasi dan ekologi manusia. Bogor (ID). Institut Pertanian Bogor.

Mustofa MS. 2011. Perilaku Masyarakat Desa Hutan Dalam Memanfaatkan Lahan Di Bawah Tegakan. Jurnal Komunitas. [internet]. [diacu 2014 September 19];3(1):1-11. Terdapat dari: http://journal.unnes. ac.id/nju/index.php/

Prabowo A, Basri E, B FA, Sudaryanto B, Bahri S. 2002. Kajian sistem usahatani ternak kambing pada perkebunan kakao rakyat di Lampung. Seminar Nasional Sistem Integrasi Tanaman-Ternak.Lampung (ID).

Sagala P. 2002. Mengelola lahan hutan yang benar. Jakarta (ID): Yayasan Obor Indonesia.

Sambodo T. 2004. Analisis regulasi dan implementasi kebijakan Taman Nasional Kutai [tesis]. Semarang (ID). Program Pascasarjana Universitas Diponegoro. 
Setyopurwanto D, Pudjihardjo M. 2013. Pengaruh investasi sumber daya manusia dan investas i modal terhadap pendapatan perkapita masyarakat Indonesia. [internet]:1-17. [diacu 2014 Oktober 29] Terdapat dari: http://jimfeb.ub.ac.id/index.php

Singarimbun M, Sofian E. 1989. Metode penelitian survai. Jakarta (ID): LP3ES.

Slamet HRM. 2003. Membentuk pola perilaku manusia pembangunan. Bogor (ID): IPB Press.

Soetarto E. 2007. Ekologi Manusia. Adiwibowo S, editor. Bogor (ID): Fakultas Ekologi Manusia- IPB.

Vogt KA, Patel-Weynand T, Muller GK, Vogt DJ, Honea JM, Edmonds RL, Sigurdandottir R, Andreu MG. 2007. Forests and society: Sustainability and life cycles of forests in human landscapes. Vogt KA, Vogt DJ, Edmonds RL, Honea JM, Patel-Weynand T, Sigurdandottir R, Andreu MG, editor. London (UK): Cromwell Press.

Widodo T. 2006. Pemberdayaan masyarakat miskin sekitar hutan melalui pengembangan $\mathrm{k}$ e le $\mathrm{m} \mathrm{b}$ a g a a $\mathrm{n}$ pengelolaan hutan berbasis masyarakat [tesis]. Bogor (ID). Sekolah Pascasarjana. Institut Pertanian Bogor. 